\title{
anatomy
}

\section{A general evaluation of the problems of anatomy education in Turkey}

\author{
Mustafa Cenk Yılmaz ${ }^{1}$, Mehmet Ali Güner ${ }^{1}$, İbrahim Tekdemir ${ }^{1}$, Mehmet Ersoy $^{2}$ \\ ${ }^{1}$ Department of Anatomy, Faculty of Medicine, Ankara University, Ankara, Turkey \\ ${ }^{2}$ Emeritus Professor of Anatomy, Ankara, Turkey
}

\begin{abstract}
Medical education development is a continuous process. Anatomy is the basis of medicine and needs to conform to the requirements of the era by applying new teaching methods and contributing to the development of scientists who can meet global standards. New visual materials and three-dimensional anatomy models are increasingly being used in anatomy training. The contribution of these methods to anatomy training will be substantial. However, it is obvious that the new educational methods will be more effective when used with cadavers, a classic and fundamental part of anatomy training. In this review, presenting the results of the various studies conducted on anatomy education, we aim to contribute to further studies on anatomy education and its curriculum in Turkey.
\end{abstract}

Keywords: anatomy education; cadaver; medical education; three-dimensional anatomy models

Anatomy 2015;9(3):182-184 @2015 Turkish Society of Anatomy and Clinical Anatomy (TSACA)

\section{Introduction}

Medical scientific studies and the rapid increase in new discoveries in recent years have created difficulties wth the compliance of medical education to the rapidly developing medical technology. Medical education must create physicians who can adapt to evolving technology. Otherwise, this developing technology will not be used sufficiently for patient benefit.

Anatomy, as the basis of medicine and anatomy education, is also affected by this problem. There are various studies and publications on the structure of anatomy education and its future direction. The educational process is dynamic with an increase in the use of some new methods and a reduction in the importance of other methods over time, and it is normal for some educational methods to be completely abandoned.

\section{Core anatomy curricula in Turkey}

One of the essential studies conducted on anatomy education process in our country was the creation of the Anatomy Specialization Education Curriculum. The
Anatomy Core Education Program was prepared in 2007 by the Turkish Society of Anatomy and Clinical Anatomy. ${ }^{[1]}$ The final version of the Anatomy Specialization Education Core Curriculum was prepared in the Anatomy Curriculum Commission workshops conducted in Antalya (2010) and Ankara, and became official after being approved by the Medical Specialty Board in 2015. . $^{[2]}$

The Anatomy Specialization Education Core Curriculum was prepared to identify the minimum standards in anatomy specialization and to train anatomists in Turkey according to global standards. The aim was to train anatomists who could contribute greatly to science. The Anatomy Specialization Education Core Curriculum national capability framework defines the qualifications that should be obtained by the residents specializing in anatomy.

\section{Studies on anatomy education in Turkey}

Various studies conducted on the anatomy education process have produced a wide range of conclusions. These studies have evaluated the use of cadavers in the 
anatomy education process, the duration of anatomy education, and the use of models and other three-dimension educational materials.

A study from Ankara University entitled "The evaluation of the anatomy course teaching and learning process" performed in 1998 evaluated the content of the anatomy class, difficulties students face in learning the subject, and the content and duration of the class in a total of 107 students in first to fifth year of education. ${ }^{[3]}$ This study summarized the problems faced by teaching and learning anatomy as follows:

- The inability of the students to access the written and visual materials such as lecture notes and books in time,

- Crowded classes,

- Difficulties in learning due to the narration-based teaching methodology,

- Insufficient use of visual and auditory materials and technology during the teaching process,

- Inadequate practical application hours,

- Difficulty in accessing faculty members,

- Inadequate cadaver use.

In another study performed in 2012 in Uludağ University, Bursa, Turkey by Ari et al. ${ }^{[4]} 191$ fourthsemester students commented on anatomy education as follows:

- Cadaver study must be included in the education,

- The feeling of being part of a medical school should be reinforced through anatomy education,

- The relevant clinical knowledge should be provided during the anatomy lessons.

Computer-supported three-dimensional study materials were reported to be increasingly supported in this study, but there were also continuing doubts. These have increasing use instead of cadavers in anatomy education, and will be used even more commonly in the future. However, general belief is that the importance of cadavers in anatomy education has never decreased.

Ögenler et al., ${ }^{[4]}$ in 2014, collected the opinions of 80 anatomy lecturers from 35 universities in Turkey on the use of cadavers in anatomy education. In their findings,

- Approximately $83 \%$ of the faculty members were demonstrating on cadavers,

- Cadaver was thought of as a material that should be valued and respected, and buried with a ceremony at the end of the education process,
- The use of a cadaver was believed to contribute positively to the professional identity development of physician candidates.

However, superiority of three-dimensional anatomy models to a cadaver was the least accepted opinion by the anatomy lecturers in the same study.

Anatomy education and the methods and tools used in this process continue to develop in Turkey and worldwide, and the discussion on how anatomy education should take place during this process is extremely dynamic. The general results of the relevant studies is that new visual materials and three-dimensional visual systems are being rapidly adapted to anatomy education. These new learning and teaching methods will enable world-class medical education.

One of the essential problems of anatomy education is the overcrowded classes. This can cause serious problems in the learning and teaching process, and especially hinder training using cadavers.

Cadavers will always continue to be essential for anatomy education. Although $t$ contribution of the new three-dimensional visual systems to anatomy education decreases cadaver use, anatomy education conducted without a cadaver is generally not accepted by the anatomists. Medical students demand increased practical courses and study with cadavers during anatomy education and complain about the overcrowded classrooms.

\section{Conclusion}

Medical education aims to ensure that students achieve good educational opportunities. Anatomy education models will continue to develop with advances in medical science. Making some changes and adaptations during this process is essential. The curriculum studies conducted in recent years and the identification of core education standards in anatomy education for the first time should be seen as a positive development for the future of anatomy education. The training of anatomists that may contribute to science at global standards will be the most important outcome of these studies and efforts.

\section{References}

1. Türk Anatomi ve Klinik Anatomi Derneği Çekirdek eğitim programı. İstanbul: Deomed; 2007.

2. Acuner AM, Yalçın M, Ersoy M, Tekdemir İ, Ersoy F. Ankara Üniversitesi Tıp Fakültesi anatomi dersine ilişkin öğretme-öğrenme sürecinin değerlendirilmesi. Ankara Üniversitesi Tıp Fakültesi Mecmuası 1999;52:211-8. 
3. Arı İ, İrgil E, Kafa İM, Şendemir E. Bir anket çalışması: Anatomi eğitimi ve öğrencilerin düşünceleri. Uludağ Üniversitesi Tıp Fakültesi Dergisi 2003;29:15-8.

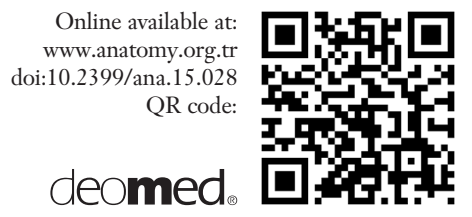

4. Ögenler O, Kara A, Kadıŏglu S, Öztürk H, Sungur MA. Opinions of a group of anatomy instructor on cadaver and utilization of cadaver in anatomy teaching. Turkish Journal of Bioethics 2014;1:57-68.

Correspondence to: Mustafa Cenk YIImaz, MD

Department of Anatomy, Faculty of Medicine,

Ankara University, 06100, Sinhiye, Ankara, Turkey

Phone: +90 3125958297

e-mail: mcyilmaz@ankara.edu.tr

Conflict of interest statement: No conflicts declared.

This is an open access article distributed under the terms of the Creative Commons Attribution-NonCommercial-NoDerivs 3.0 Unported (CC BY-NCND3.0) Licence (http://creativecommons.org/licenses/by-nc-nd/3.0/) which permits unrestricted noncommercial use, distribution, and reproduction in any medium, provided the original work is properly cited. Please cite this article as: Y1lmaz MC, Güner MA, Tekdemir İ, Ersoy M. A general evaluation of the problems of anatomy education in Turkey. Anatomy 2015;9(3):182-184. 